\title{
The fiscal capacity of local government versus govern- ment expenditure, and its impact on eliminating inter- regional social inequalities in Poland
}

\author{
Małgorzata Gałecka $^{1}$, Leszek Patrzałek ${ }^{1}$, Ireneusz Kuropka ${ }^{1}$, Ewa Szabela- \\ Pasierbińska ${ }^{1}$
}

${ }^{1}$ Wroclaw University of Economics and Business, Wroclaw, Poland

Received: 21 May 2021/Accepted: 23 December 2021

\begin{abstract}
Social inequalities are a significant challenge in developing countries. Therefore, they should be treated as a leading priority in boosting socio-economic development. Such inequalities are a growing challenge for Poland. It is believed that social inequalities are behind Poland's relatively low position against other European countries in the Human Development Index ranking. Many factors influence social inequalities, one being the system of financing local government units. A critical area for considering social inequalities in the context of financial phenomena is the study of fiscal inequalities resulting from the implemented vertical division of public revenues among individual levels of public authority. The paper presents the results of research on the relationship between the fiscal capacity of local government units in Poland across voivodeships and the expenditure of government institutions, as well as the relationship of these expenses with social inequalities in voivodeships. To this end, six areas of social life were distinguished, for which the degree of inequality of transferred expenditure was determined using the Gini index. The method of the total order of objects was used to assess the impact of government institutions' expenditure on an individual's social situation across voivodeships. The conducted research showed both the weak dependence of government expenditure on individual units' fiscal capacity and its low effectiveness in eliminating inter-voivodeship social inequalities.
\end{abstract}

JEL classification: $\mathrm{H} 20, \mathrm{H} 5, \mathrm{H} 70, \mathrm{R} 12$

Key words: fiscal capacity, tax capacity, local government units, social inequalities, interregional diversity

\section{Introduction}

In the past decade, the issue of social inequality has been the subject of growing interest in debates between economists (Piketty 2005). Nowadays it has reached a level where it inhibits growth, weakens the economy (Thiessen 2003) and contributes to rapidly increasing social stratification. These phenomena are exacerbated by globalisation processes, market openness, technological progress, deregulation of the financial sector, 
polarisation of labour markets, erosion of labour market institutions, and a weakening of tax system progressivity.

An important domain for considering social inequalities in the context of financial phenomena is the study of fiscal inequalities resulting from the implemented vertical division of public revenues and tasks among individual levels of public authority. The theory of fiscal federalism shows that decentralisation enhances economic efficiency. Local governments know local conditions and preferences regarding the provision of public goods better than the national government sector does due to their physical and institutional proximity (Oates 2006). These information advantages should enable local governments to provide public goods and services that better match local preferences and/or deliver the same public goods and services at a lower cost. Equipping the budgets of local and regional units with the same sources of fiscal revenues does not guarantee similar levels of fiscal capacity. In economics, fiscal potential can be defined as tax capacity, i.e. the ability of local government units (LGU) to gain income from their own sources in order to finance standardised baskets of public goods and services (MartinezVazquez, Boex 1997). Therefore, per capita income level is considered the primary measure of LGU tax capacity (Martinez-Vazquez, Boex 1997). This income is primarily a derivative of location, natural resources, inhabitant wealth, population density and level of socio-economic development. Conversely, differences in LGU tax capacity may be reduced or increased by regionally allocating public expenditure made by government institutions (Blöchliger et al. 2016). An important factor in determining the allocation of public expenditure should be the level of LGU revenues.

Existing research carried out on the impact of government expenditure on the fiscal inequality of LGUs and, consequently, on the level of public goods and services provided to these units in a decentralised public finance system is inconclusive. Some respondents indicate that government spending does not reduce interregional inequalities (Kessler, Lessmann 2010). Other studies show that government spending may positively impact the equalisation of LGU fiscal resources necessary for the implementation of public tasks and services (Bartolini et al. 2016). The research's different outcomes are mostly due to the specific factors characterising individual countries and their regions. Consequently, the research carried out at the national level in particular countries and the conclusions drawn on this basis may differ from the results of research carried out on a regional or even local basis (Purbadharmaja et al. 2019).

Research into the economic impact of fiscal decentralization internationally, however, does not take into account the countries of Eastern Europe (Gil Canaleta et al. 2004, Lessmann 2009, 2012, Rodríguez-Pose, Ezcurra 2009). This is most often caused by the lack of available fiscal data, especially regional data for certain periods and countries. Historically, these countries had centrally planned economies, but currently they are very fast-growing agglomerations. As Lessmann (2009) rightly points out, the economic impact of fiscal decentralization in these countries may differ from other highly developed countries. This article aims to fill this gap by examining whether fiscal decentralization, which has been accepted in Poland (the largest eastern European country by population), affects fiscal inequalities between local government units in terms of voivodeships. The article does not examine the degree of fiscal decentralization; we focus on its economic effects, such as inter-regional social inequalities.

Social inequalities are becoming an increasing challenge. It is believed that social inequalities are behind Poland's relatively low position vis-à-vis other European countries in the Human Development Index (HDI) ranking (UNDP 2020). This article argues that the LGU financing model adopted in Poland does not improve inter-voivodeship social inequalities. We conducted research with the following objectives:

1. evaluation of the level of LGU tax capacity differentiation in the level of voivodeships;

2. identification of the relationship between the expenditure of government sector institutions and LGU tax capacity by voivodeships;

3. determining whether and to what extent the allocation of national public funds across voivodeships by government institutions contributes to reducing social inequalities in these voivodeships. 
At the same time, we put forward the hypothesis that public expenditure of government institutions across voivodeships has low effectiveness in reducing social inequalities among regions.

In this study, we have analysed the relationship between government spending in health, science and education, welfare, infrastructure, culture and environmental protection, and social inequalities in 16 voivodeships (NUTS-2) in Poland between 2010 and 2018. At the same time, we have researched the correlation between government expenditure in Poland and LGU tax capacity across voivodeships. To this end, we used financial data obtained from reports and financial statements of central and local government institutions and data from Statistics Poland. In order to show the degree of LGU tax capacity from the perspective of voivodeships, the tax revenues of all local government units of a given voivodeship were taken into account.

The conducted research showed the different level of tax revenues of LGU and weak dependence between government expenditure and individual units' fiscal capacity, which may result in its low effectiveness in eliminating inter-voivodeship social inequalities. The allocation of public funds of government institutions in the long term does not improve differentiation between voivodeships. Minimal changes in the Gini coefficient value would instead be shown to stay at a certain level rather than improve the differentiation between LGU in terms of voivodeships.

This work is structured as follows. The literature on government expenditure and LGU fiscal inequalities is discussed in Section 2. The dataset and variables used for the analysis are presented in Section 3. Section 4 discusses the main results and conclusions.

\section{Literature Review}

In the theory of fiscal federalism, the issue of differences in LGU tax capacity is researched mainly from the perspective of the decentralisation of public authorities. Solutions are sought to determine the optimal degree of fiscal decentralisation of the public sector and demonstrate which functions and instruments should be within the government administration's competence and which should be entrusted to decentralised local government units. The starting point for researchers looking for the optimal degree of fiscal decentralisation are theses promoted by Musgrave (1959). When analysing the benefits and threats of fiscal decentralisation, Musgrave stated that the process might significantly impact increasing inequalities in the fiscal potential of local government units.

Fiscal decentralisation has the potential for poverty reduction when characterised by greater financial autonomy of local units with proper budgetary allocation, prioritisation, accountability and responsiveness (Agyemang-Duah et al. 2018). Otherwise, decentralisation can lead to a growing gap between regions due to the weak skills of local and regional authorities in managing public resources and services (Lessmann 2006). The local government taxes are usually less progressive than those which go to the state budget (Rubolino 2019, Wong 2004). Wong's research on the relationship between local economic growth and local government tax capacity showed that high property taxes are strongly negatively correlated with the local governments' ability to generate income (Wong 2004). If tax decentralisation leads to greater dependence of the public finance system on these instruments, then the tax system's overall progressivity usually shrinks. This, in turn, leads to the emergence of greater income inequalities. Rodríguez-Pose, Ezcurra (2009) outline a similar opinion. Their research shows that the relationship between decentralization and the evolution of disparities at the subnational level seems strongly affected by the level of wealth of a country, the dimension of its existing disparities, and the presence of solid fiscal redistribution systems. High income countries, with limited internal disparities, a strong welfare state, and territorially progressive fiscal systems can expect that decentralization will not harm their territorial cohesion. The situation can be different in low and medium income countries especially in the absence of well-established territorially progressive fiscal systems.

Government institution spending may minimise fiscal inequalities, but it depends on numerous factors and even at a high level in a particular region, this may not improve its social inequalities (Purbadharmaja et al. 2019). According to Kessler, Lessmann's (2010) 
research on 22 highly developed OECD countries, significant government replenishment of LGU income can lead to increased interregional inequality. The evidence presented by the authors suggests a positive relationship between interregional transfers and regional disparities both across countries and in the longer term. According to the authors, countries with higher levels of interregional redistribution in the past show a subsequent increase in interregional disparity, while countries with lower levels of grants and transfers show less divergence or even convergence. Conversely, Bartolini et al. (2016) indicate that higher transfer dependency could help equalise the fiscal resources necessary for lagging regions to achieve minimum standards in the provision of subnational goods and services conducive to regional convergence. However, from a public choice perspective, it is not necessarily the case that a centralized system redistributes to poorer regions. Richer regions are often disproportionately stronger negotiators then poorer regions. Those regions therefore have a larger impact on the regional policies of the central government, possibly leading to a reduction in inter-governmental transfers to needy regions (Lessmann 2009). On the other hand, Bartolini et al. (2016) point out that government expenditure on behalf of LGUs should be combined with providing local governments with an appropriate base of their own revenues. According to Shah (1994), this should positively affect the reduction of government transfers' adverse effects. Otherwise, government transfers may discourage the economic development of less developed regions. The forms and scope of transferring public funds from the central level towards the implementation of public tasks of a local and regional nature are therefore aimed at the efficiency of the public sector. (Oates 1972, Buchanan 1950, Boadway 2008). Oates (1999) argues that a higher efficiency of public expenditure is achieved when the level of revenues allocated to LGUs enables the provision of public services of a similar or required standard. In particular, fiscal decentralisation fosters regional convergence under highquality governance but, disturbingly, leads to wider regional disparities in mismanaged countries (Kyriacou et al. 2015).

The issue of fiscal inequalities between municipalities/regions is taken up in theories of local and regional development based on endogenous resources (Romer 1994). They assume that local government units affect labour markets, support the development of small and medium-sized enterprises, ensure favourable conditions for the development of enterprises located in a given territory, and undertake public investments in infrastructure. In the context of government administrations influencing development through extensive instruments of various economic policy fields (in addition to fiscal and monetary policy, also through employment, innovations and industrial policy), intervention in the socioeconomic space may distort the market conditions of management (Yuanshuo, Warner 2016). Especially if the overall context of the socio-economic development of the region is not taken into account, for example, through the complex indicator of the supported development sectors (Mohiuddin, Hashia 2012). National governments need to consider how best to rationalize public investment, and new tools are necessary to guide and prioritize these investments (Márquez et al. 2017). Hence, the government administration's broader engagement in the sphere of regional development may result in an inefficient spending of the limited resources of public funds, the growth of bureaucracy supervising this activity, the consolidation of ineffective institutional structures, the introduction of regulations inhibiting entrepreneurship, and the development of bottomup mobilisation of endogenous potentials. To propose more targeted and practicable policy, it is important to take into account the developmental characteristics of individual regions, perform research classifying smaller geographical areas and a greater number of narrower economic sectors. (Christofakis et al. 2019).

LGU financing systems differ significantly from one OECD country to another. This can be mainly seen in the structure of individual sources of income, including LGU income. The share of the latter in total income is often indicated in the literature as a measure of LGU income independence. Scandinavian countries are characterised by the greatest degree of fiscal autonomy, where the LGU income system relies on local income tax. On the other extreme, there are countries such as Ireland or the Czech Republic, where transfer revenues play a significant role. In Romania, the main problem remains the deeper decentralisation of competences and the de facto financial independence of 
local government (Alexandru, Guziejewska 2020).

Among the analysed countries, Poland has one of the lowest shares of tax revenues over which LGU exercise tax control (OECD 2019). According to Polish legislation, the LGUs' own income does not involve general subsidies and specific subsidies from the state budget. In this respect, LGUs' own income is sourced from, inter alia, shares in income tax from the state budget, over which the local government has no tax control.

In the countries of Eastern Europe, a significant challenge is equalising LGU income, including transfers of funds between the central and local governments. In Poland this issue has been going on since the 1990s. However to this day, an entirely acceptable form of local government revenue system has not yet been developed. Consequently, the structure of the Polish public revenue system requires partial financing of the local government subsector's tasks with funds at the disposal of government subsector institutions. Issues regarding the coordination of Polish local government and government institutions' fiscal decisions related to the allocation of public funds in LGUs are also important (Kańduła 2017, Patrzałek et al. 2019). With insufficient knowledge of the priorities in implementing public tasks in municipalities, poviats and voivodeships, the cooperation of local government authorities with government institutions is difficult. Such a situation is not conducive to the coordination of fiscal decisions related to the allocation of public funds in the level of voivodeships, and the coherence and complementarity of individual levels' fiscal decisions concerning budgetary expenditure allocation. It also does not support the effective and economical allocation of public expenditure for purposes related to strengthening the regions' competitiveness.

\section{Research Methods}

We examined the relationship between the expenditure of government sector institutions, LGU tax revenues and the social situation in individual regions between 2010 and 2018.

The expenditures of government sector institutions included funds transferred to LGU in voivodeships for the following areas of social and economic life: science and education, culture, infrastructure, healthcare, social protection, and environmental protection. Health, science and education are essential areas taken into account when building the HDI index. Then, areas of economic and social life, data showing environmental pollution, and personal safety levels are recommended and used in reports published by the United Nations Development Programme as a supplement to the HDI index (see UNDP 2013).

In the study, we only included expenditure from national public sources ${ }^{1}$. No account was taken of resources from European Union funds. We obtained financial data from reports and financial statements of government sector institutions. The expenditure adopted in the study constitutes $80 \%$ of the total state budget expenditure. We included the expenditure of the institutions from the government sector in Table 1.

The level of LGU tax revenues in voivodeships is a characteristic of their tax capacity in each year of the analysis. As part of tax revenues, we included revenues from the following taxes and fees:

- LGU taxes and fees (real estate tax, agricultural tax, forest tax, tax on means of transport, tax on civil law transactions, tax on inheritance and donations, income tax on natural persons' businesses paid in the form of a fixed tax amount, market fee, service charge, stamp duty and revenues from other local fees charged by local government units based on separate acts)

- shares in Personal Income Tax (PIT) and Corporate Income Tax (CIT)

\footnotetext{
${ }^{1}$ Sources: Reports on the activities of the voivodeship fund for environmental protection and water management of a given voivodeship for 2010-2018; Report MRP\&PS-02 - a collective report on the income and expenditure of the labour fund of voivodeship labour offices for the years 2010-2018; Report on the implementation of the material and financial plan for the activities of the State Fund for the Rehabilitation of Disabled People in 2010-2018; Report on the implementation of the state budget, part 24 - Culture and protection of national heritage for the years 2010-2018; Data provided by the Ministry of Science and Higher Education and the Social Insurance Institution for the years 2010-2018; Information on the implementation of the budget of local government units for four quarters from 2010-2018; Report on the implementation of the state budget for 2010-2018.
} 
Table 1: List of government expenditures included in the study

\begin{tabular}{|c|c|}
\hline Area & Variables \\
\hline Science and education & $\begin{array}{l}\text { Segment allocated to education of the general subsidy } \\
\text { Earmarked and targeted subsidies for education } \\
\text { Subsidies for teaching activities of universities } \\
\text { Subsidies for research activities of universities } \\
\text { Subsidies for financial support of students and doctoral candidates }\end{array}$ \\
\hline Culture & $\begin{array}{l}\text { Earmarked and targeted subsidies for current and capital expenses } \\
\text { subordinate to the Ministry of Culture and National Heritage } \\
\text { Voivodes' expenditure on culture and protection of national heritage } \\
\text { Voivodes' expenditure on physical culture and sports }\end{array}$ \\
\hline Infrastructure & $\begin{array}{l}\text { Transport and communication expenses } \\
\text { Voivodes' expenditure on housing }\end{array}$ \\
\hline Healthcare & $\begin{array}{l}\text { National Health Fund expenditure on healthcare, including expenses on } \\
\text { the cost of health services and emergency medical services } \\
\text { Voivodes' expenditure on healthcare }\end{array}$ \\
\hline Social protection & $\begin{array}{l}\text { Labour Fund expenditure, including unemployment benefits and } \\
\text { programmes to help employees } \\
\text { Social Insurance Institution expenditure, including expenses on social } \\
\text { insurance } \\
\text { State Fund for the Rehabilitation of Disabled People expenditure, } \\
\text { including expenses on vocational and social rehabilitation } \\
\text { Voivodes' expenditure on social assistance and the "Family" programme }\end{array}$ \\
\hline Environmental protection & $\begin{array}{l}\text { Expenditure by Provincial Funds for Environmental Protection and } \\
\text { Water Management (WFOS\&GW), including expenses on climate, land } \\
\text { and water protection } \\
\text { Voivodes' expenditure on municipal management and environmental } \\
\text { protection }\end{array}$ \\
\hline
\end{tabular}

Source: see footnote 1 on page 55 .

The social situation is a complex phenomenon that can be understood and characterised in various ways. In the study, we have used the variables available from the Local Data Bank to describe the phenomenon in the voivodeships under consideration (Statistics Poland 2010). The list of areas under consideration, together with the variables adopted in the study, are presented in Table 2.

The presented variables were expressed in relative terms. They were selected based on the substantive analysis of the studied phenomenon and the availability of statistical data that can be used to characterise the social situation in LGUs. As shown in Table 2, a total of 12 variables were used. For such a number of variables, the assessment of the impact of government institution expenditure on the social situation in LGUs by voivodeship required the construction of a synthetic measure that would allow the assessment of changes that took place in particular voivodeships between 2010 and 2018. To this end, we used the relative level of development index (BZW), which is a method of ordering objects used in the study of the spatial differentiation of multi-feature objects (Młodak 2006). This measure uses the sum of standardised values and is a normalised measure without a standard - its values range from 0 to 1 . The closer the value is to 1 , the better the studied object is according to the adopted general criterion. The following formulas are used to determine the BZW index (Grabiński et al. 1989):

$$
\begin{aligned}
W_{i} & =\frac{\sum_{j=1}^{k} z_{i j}}{\sum_{j=1}^{k} \max _{i}\left\{z_{i j}\right\}} \\
Z_{i j} & =x_{i j}^{*}+\left|\min _{i}\left\{x_{i j}^{*}\right\}\right| \\
x_{i j}^{*} & =\frac{x_{i j}-\bar{x}_{j}}{s_{j}}
\end{aligned}
$$

where $W_{i}$ - BZW relative level of development index for the $i$-th object; $x_{i j}$ - value of 
Table 2: List of areas with the variables adopted in the study

\begin{tabular}{ll}
\hline Area & Variables \\
\hline science and education & R\&D expenditure per capita \\
& pupil per section in primary schools \\
& percentage of children aged 3-6 covered by pre-school education \\
& number of people per seat in theatres and musical institutions \\
number of museums, including departments, per 100 thousand & inhabitants \\
culture & length of public roads per 10 thousand km \\
infrastructure & nopulation per 1 hospital bed \\
healthcare & unemployment rate in the voivodeship \\
social protection & number of people who were awarded social assistance per 10 \\
& thousand inhabitants \\
outlays on fixed assets for environmental protection and water \\
management per capita \\
total dust pollution per $1 \mathrm{~km} 2$ of surface
\end{tabular}

Source: Statistics Poland - Local Data Bank, http://www.stat.gov.pl/en/.

$j$-th trait for the $i$-th object (diagnostic variable) $)^{2} ; \bar{x}_{j}, S_{j}$ - arithmetic mean and standard deviation of the $j$-th feature respectively.

The BZW index is a synthetic measure often used to describe complex phenomena in various areas, including an analysis of the capital market and real estate market, the effects of activities using EU funds or showing the degree of differentiation in access to cultural services (Łuniewska, Tarczyński 2006, Mazur, Witkowska 2006, SzabelaPasierbińska 2018, Gałecka, Smolny 2019).

The government sector institutions' level of expenditure and LGU budget revenues in individual voivodeships between 2010 and 2018 varied significantly. Therefore, when assessing their changes, we used relative increments, thus ensuring the comparability of these changes. Using the Gini coefficient, we determined the degree of inequality of government sector institutions' expenditure allocated to the selected areas of social life. The Gini coefficient is the most frequently used measure to assess income inequality (Gil Canaleta et al. 2004). In this case, government sector expenditure can be interpreted as a type of income, enabling the implementation of specific tasks in the LGU.

We characterised the differentiation of expenditure in subsequent years with the coefficients of variation. This statistical parameter also enabled the variability of the LGUs' social situation to be assessed against BZW in 2018 compared to the study's baseline year. In order to determine the degree of the relationship between the LGUs' tax revenues and the government sector institutions' expenditure, we used the basic measures of dependence, i.e. correlation coefficients.

\section{Results}

LGU tax revenues constitute the fundamental source of funding for many social expenses and those that should provide citizens with access to many public services at a level comparable across the country, among other things. Therefore, the appropriate coordination and implementation of the system is an important issue that allows for a reduction of excessive inequalities in income, and thus limits the existing inequalities within the scope of the public services provided.

\subsection{The level of LGU tax capacity differentiation in voivodeships}

Between 2010 and 2018, the level of LGU tax revenues in Poland varied significantly. When analysing the ratio of tax revenues of LGU budgets per capita in terms of voivode-

\footnotetext{
${ }^{2}$ The variables must be stimulants.
} 


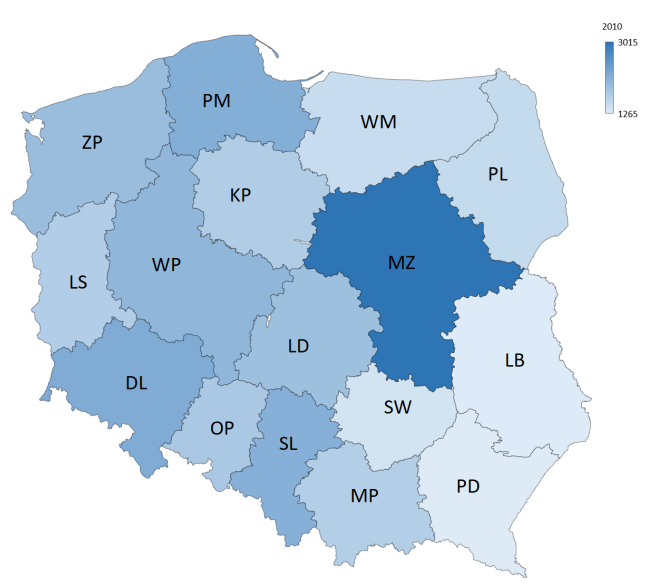

(a) 2010

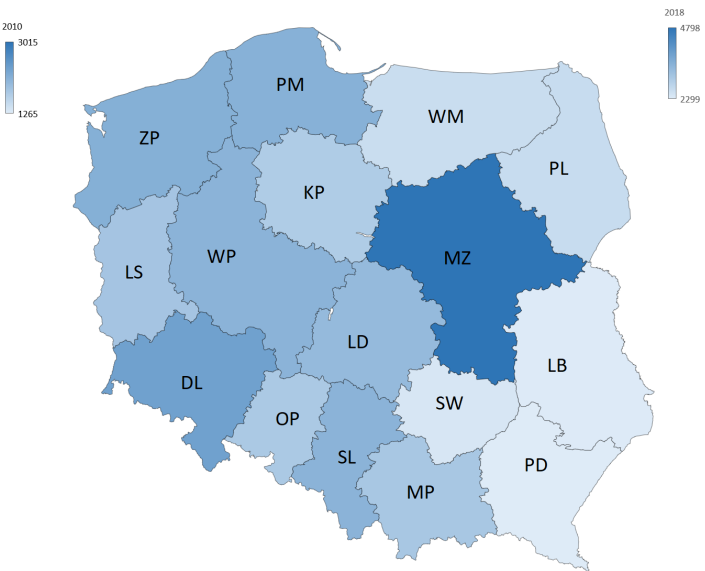

(b) 2018

Source: own study based on GUS data.

Figure 1: LGU tax revenue per capita by voivodeship in 2010 and 2018, PLN

ships, a regularity is seen indicating a better budgetary situation of LGU in western and northern Poland, i.e. where agriculture plays a less critical role then entrepreneurship (Figure 1). Western Poland has a more favourable geopolitical situation which encourages international relations. It is adjacent to Poland's largest economic partner and through the sea to the Baltic States. The units of self-government located in Western Poland are involved in numerous forms of international cooperation, such as Euroregions. The immediate neighbourhood with a developed area generates circular economic migration that the municipalities of Western Poland are subject to. These migrations have a twofold impact on the development of the areas where workforce migrates: a decrease in unemployment and the inflow of capital, which has a positive impact on tax revenues of individuals LGU. In addition, the population density in Western and Northern Poland is much higher than in the East.

The lowest values of the index are recorded in the provinces: Podkarpackie (PD), Podlaskie (PL), Lubelskie (LS), Świętokrzyskie (SW) and Warmińsko-Mazurskie (WM). At the same time these provinces constitute the macro-region of Eastern Poland. The peripherality of Eastern Poland has not only a spatial dimension (defined by the distance from the development centres of Poland and the European Union), but also a socioeconomic dimension. The level of economic development of these areas is among the lowest in the European Union. Innovation, competitiveness and investment attractiveness are very low there, which is reflected in the income of units of territorial self-government. Late development of the macro-region has deep historical roots and is an example of long-term processes (Kukliński 2010). In addition, on a macro-regional scale, a higher than average proportion of its surface area nationally is covered by different legal forms of environmental protection (39.4\%, with a national average of $32.5 \%$ ), which also translates into lower revenues for the units of territorial self-government budget. For this reason, the index's lowest values are recorded in the eastern part of the country, where agriculture plays an important role.

In 2010, LGU tax income per capita in the richest voivodeship in Poland (Mazowieckie - MZ), from a tax revenue point of view, accounted for $138 \%$ of similar income of LGU located in the poorest voivodeship (Podkarpackie - PD). In 2018, the difference decreased to $109 \%$, indicating a certain reduction in the disparities between voivodeships in terms of LGU tax revenue. In the western part of Poland, much smaller spatial differences in LGU tax revenues are observed. In 2010-2018, the increase in LGU tax revenues per capita, measured by relative increase, ranged from $59 \%$ to $83 \%$ (Figure 2).

Significant differentiation of the increase in tax revenues in individual voivodeships has resulted, among other reasons, from the increase in these revenues of the share of 


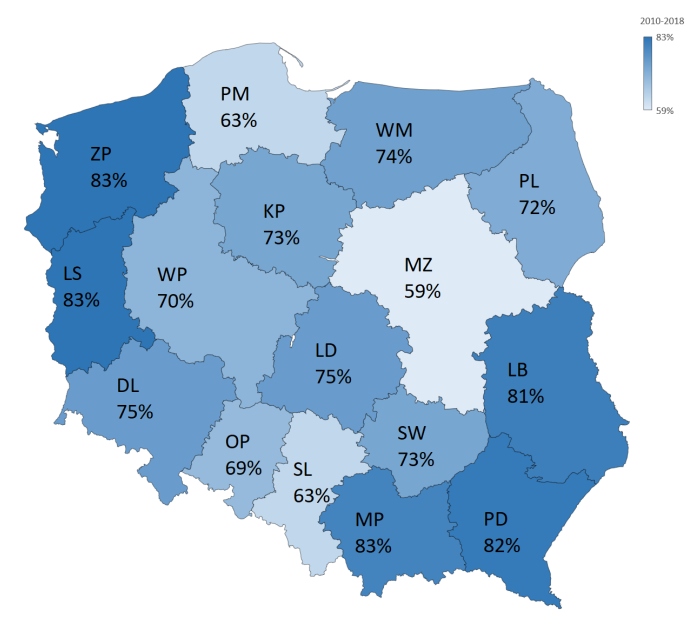

Source: own study based on GUS data.

Figure 2: Increase in LGU tax revenue per capita by voivodeship and its increase (\%) in 2010-2018

PIT and CIT (which was particularly noticeable in 2015-2018). It should be noted that in the majority of municipalities with rural areas, the CIT is minimal while the PIT in typically agricultural communes is not decisive. Despite large increases in tax revenues, interregional differentiation is still significant in the eastern part of the country. The increase in tax revenue in the Eastern Poland provinces shows the limitation of the role of agriculture in their territory (in favour of the development of tourism, for example).

\subsection{Expenditure of government sector institutions and LGU tax capacity by voivodeship}

The diversified level of LGU tax revenues required a systematic increase in government expenditure by voivodeship. When analysing the relative increases in government expenditure, the lowest (below 40\%) is noted in the Mazowieckie (MZ) voivodeship (Figure 3). The research showed that the differentiation of government expenditure in individual voivodeships was smaller than the differentiation of these voivodeships' tax revenues.

In 2010, the highest expenditure of government institutions was recorded in LGUs in the Mazowieckie (MZ) Voivodeship - the richest in terms of tax revenues per capita. In the following years, the expenditure policy of government sector institutions changed and, in 2018, the group of voivodeships with the highest share in government expenditure included: Podkarpackie (PD), Świętokrzyskie (SW) and Warmińsko-Mazurskie (WM). It is worth recalling that these were the voivodeships with the lowest tax revenues (per capita). Changes in the average level of government expenditure (by voivodeship) and the average level of LGU tax revenues (by voivodeship) in 2010-2018 are shown in Figure 4. The arrangement of points in the chart shows that if there is a relationship between the government sector expenditure by voivodeship and LGU tax revenues, this is weak.

The correlation coefficients between government expenditure and LGU tax revenues in individual voivodeships for 2011-2018 were negative ${ }^{3}$, but their values did not indicate a strong relationship (Table 3). It can even be said that in 2010 and 2011 there was no relationship between these variables. In the rest of the years, the relationship was weak, and only in 2013 was the absolute coefficient value higher than 0.5 .

The negative correlation means that following the decline in LGU tax revenues in particular voivodeships, government expenditure in these regions increased. Generally, this is the right course of action and shows a weak relationship between government sector institutions' expenditure and LGU tax capacity across voivodeships. This means

\footnotetext{
${ }^{3}$ In 2010, the correlation coefficient was positive and amounted to 0.14 .
} 


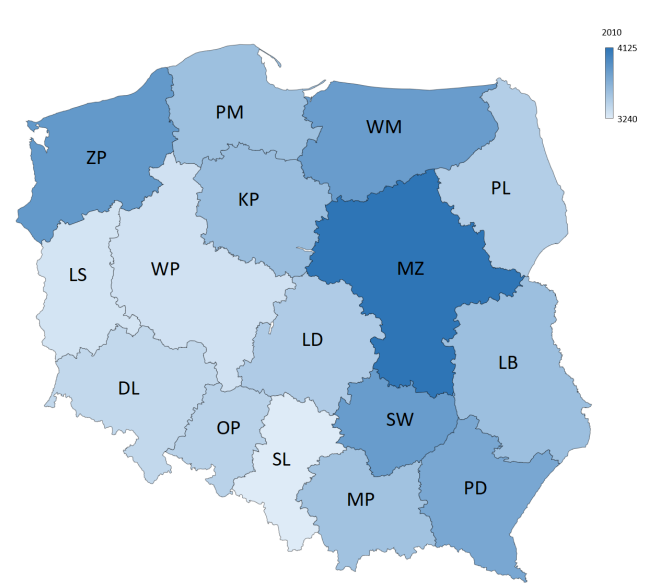

(a) 2010

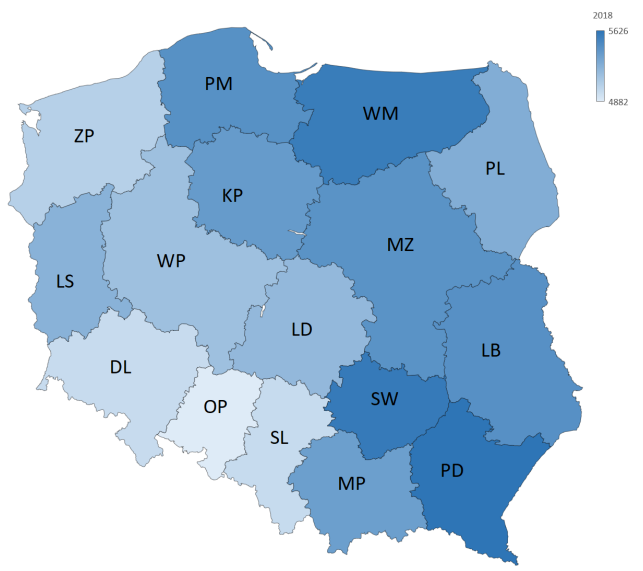

(b) 2018

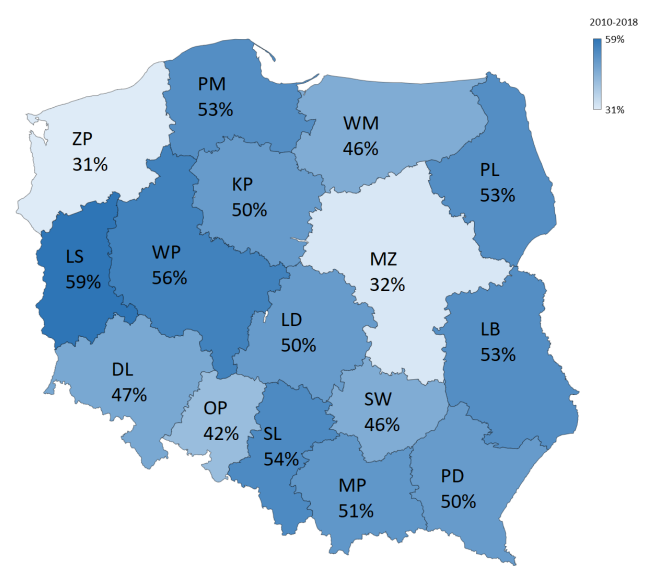

(c) 2010 to 2018 in $\%$

Source: own study based on GUS data.

Figure 3: Government expenditure per capita by voivodeship and its increase (\%) in 2010-2018, PLN

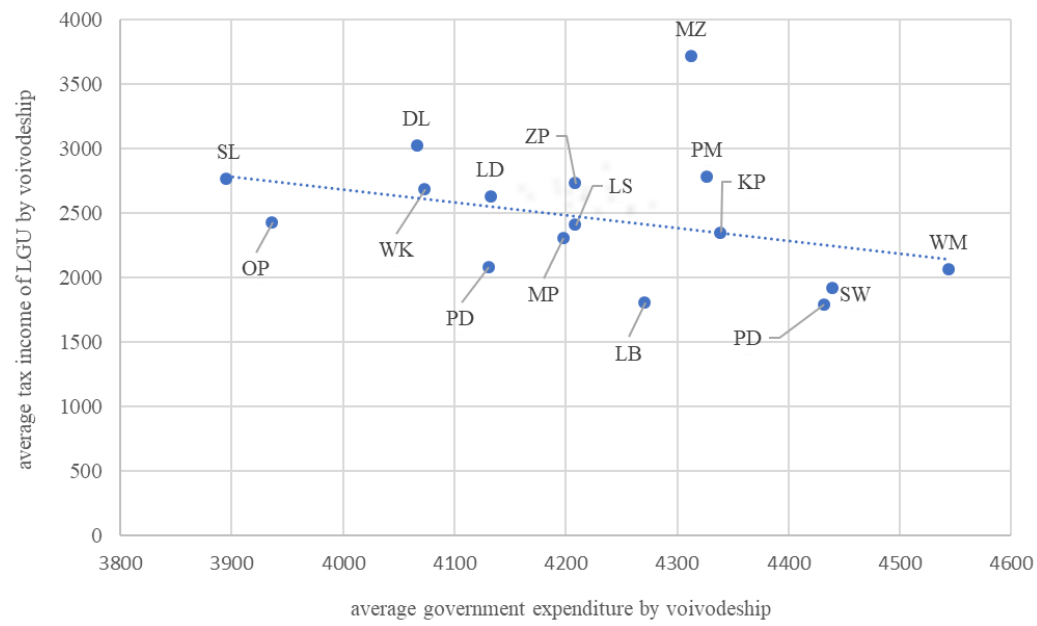

Source: own study.

Figure 4: Average government expenditure (in terms of voivodeship) versus average tax revenues of LGU (in terms of voivodeship) in 2010-2018 in Poland 
Table 3: Correlation between government expenditure in the region and LGU tax revenues, per capita

\begin{tabular}{ccccccccc}
\hline 2010 & 2011 & 2012 & 2013 & 2014 & 2015 & 2016 & 2017 & 2018 \\
\hline 0.1431 & -0.1394 & -0.293 & -0.5319 & -0.4404 & -0.3786 & -0.4354 & -0.3499 & -0.4112 \\
\hline
\end{tabular}

Source: Own study.

that support is provided to voivodeships with less favourable development conditions, which thus gain adequate resources to eliminate development barriers and stimulate sustainable growth. It is also consistent with the theory of welfare economics, where income disparities can be reduced not only through taxes but also transfers, so that the distribution of income is more even (Pigou 2010). The relatively low values of correlation coefficients between government expenditure and LGU tax revenues, also suggest the need to review the equalisation system and the allocation of public funds from the national level to LGU budgets currently in force in Poland. The level and direction of government expenditure by voivodeships as the primary mechanism of equalising social inequalities should take into account expenditure needs related to the implementation of public tasks in LGUs with low-income potential. In this context, however, it is necessary to take into account the scope of LGU tasks of different LGU levels and the adequacy of resources (tax revenues and other financial tools) at their disposal. This will help determine which of these tasks should be implemented solely with the use of an LGU's own resources, and which will require external support (including financing).

\subsection{Allocation of national public funds versus social inequalities by voivodeships}

The analysis of the coefficients of variation showed that the most extensive spread of expenditure by government institutions was in the area related to culture. Large dispersion of government spending across voivodeships also occurred in social protection, environmental protection and infrastructure. The smallest spatial differentiation of government expenditure was recorded in healthcare, education and science. The values of the coefficient of variation of expenditure in these areas of activity did not exceed $10 \%$, indicating a slight differentiation in government institutions' expenditure across voivodeships. In the case of science and education, this decreased even more with time. Vs values reflect the spending policy applied in Poland. In areas where there are legally well-defined criteria for the redistribution of public (government) funds, the coefficient of variation is much lower than in areas where such rules are non-existent (Table 4). A good example is education, for which the government receives funds from the governmental sector as part of the so-called educational component of the general subsidy. The same is true for health protection. In other areas, where the detailed nature of the criteria for redistribution of funds is lesser or does not exist, the coefficient of variation increases. Culture is worth mentioning here. There are no criteria in Poland for allocating public funds to day-to-day activities of cultural institutions. The organizer is supposed to provide the resources needed to maintain and develop the cultural institution concerned, but there are no specific criteria for their allocation. In addition, variability is also influenced by the subsidizing of cultural events taking place in selected locations rather than in each province.

The Gini coefficient values calculated for individual areas varied (Table 5). It should be highlighted, however, that the comparison of its value in the extreme years of the period under consideration (2010 and 2018) shows that the inter-voivodeship inequalities in government institutions' expenditure in particular areas decreased slightly (except for the area of culture). This means that in the span of almost ten years, this improvement is symbolic. Simultaneously, it points to the individual nature of the support for a given area from national public funds. Lack of coordination in the areas supported by the government sector, and the support instruments and rules for their allocation, which have been operating on the same principles for many years, have not contributed to a significant improvement of the analysed inequalities. The smallest inequalities were 
Table 4: Coefficient of variation (Vs) of expenditure of government institutions in individual voivodeships, by area, $\%$

\begin{tabular}{lccccccccc}
\hline & 2010 & 2011 & 2012 & 2013 & 2014 & 2015 & 2016 & 2017 & 2018 \\
\hline $\begin{array}{l}\text { science and } \\
\text { education }\end{array}$ & 9.78 & 9.90 & 9.53 & 7.25 & 6.88 & 6.54 & 6.62 & 6.58 & 6.25 \\
$\begin{array}{l}\text { culture } \\
\text { infrastructure }\end{array}$ & 124.16 & 145.28 & 136.15 & 131.47 & 127.90 & 130.32 & 125.64 & 138.62 & 142.94 \\
$\begin{array}{l}\text { healthcare } \\
\text { social }\end{array}$ & 4.40 & 4.06 & 2.92 & 2.58 & 5.20 & 4.40 & 2.86 & 3.17 & 3.31 \\
$\begin{array}{l}\text { protection } \\
\begin{array}{l}\text { environmental } \\
\text { protection }\end{array}\end{array}$ & 22.21 & 16.13 & 16.86 & 17.08 & 17.14 & 16.70 & 13.65 & 11.42 & 10.87 \\
\hline
\end{tabular}

Source: own study based on GUS data.

Table 5: Gini coefficients by area

\begin{tabular}{ccccccc}
\hline & $\begin{array}{c}\text { science } \\
\text { and } \\
\text { education }\end{array}$ & culture & infrastructure & healthcare & $\begin{array}{c}\text { social } \\
\text { protection }\end{array}$ & $\begin{array}{c}\text { environmental } \\
\text { protection }\end{array}$ \\
\hline 2010 & 0.24 & 0.64 & 0.36 & 0.22 & 0.29 & 0.38 \\
2018 & 0.23 & 0.65 & 0.32 & 0.21 & 0.25 & 0.36 \\
\hline
\end{tabular}

Source: own study.

related to healthcare, while the largest to culture expenditure.

The research showed that the differentiation of the LGUs' social situation in the analysed areas, measured by BZW in 2018, did not change compared to the study's initial year. In 2018, the coefficient of variation of the development index was $22 \%$ compared to $21 \%$ in 2010 (Table 6 ). This proves the low effectiveness of expenditure by government sector institutions in reducing interregional social inequalities.

\section{Discussion}

The fiscal capacity of a local government unit corresponds to its ability to gain its own income in order to finance public services. As most public revenues come from taxes, this potential is often due to the LGU's ability to collect tax revenues. There are locally collected taxes, however, over which local governments have little or no control (Sorens 2011). This is the case in Poland, where municipalities have sole tax control to determine rates (within the upper rates indicated by the act) and grant reliefs or exemptions over few local taxes.

The level of Polish LGU tax capacity is hardly used to determine the allocation of funds to equalise the income of individual units and ensure adequate funds for the implementation of public tasks. Local policy activities differ basically across geographic space (Devees et al. 2003). The applied solutions do not consider factors of an endogenous nature, which strictly arise from the area's geographical location and history. This is confirmed by the diversified level of the tax revenue ratio of LGU budgets per capita in voivodeships. The indicator level noted in Western, North-Western and South-Western Poland was higher than that in eastern, north-eastern and south-eastern parts of the country. Much of this "division" is due to historical events (see more: Encyclopaedia Britannica 2020). Eastern regions do not have adequate scientific, technological or transport facilities (e.g. airports of international importance). Non-economic factors, neglected by conventional economic modelling, are of great importance in explaining fiscal decentralisation dynamics (Panizza 1999). Agriculture plays a vital role in these areas, and there are few metropolitan centres. This confirms Wong's argument (Wong 2004) that agricultural activity, and even its growth, does not positively impact on local authorities' tax capacity. In addition, rural areas are less likely than urban areas to 
Table 6: The level of social inequalities in LGU

\begin{tabular}{llcc}
\hline & & \multicolumn{2}{c}{ BZW } \\
short & Voivodeship & 2010 & 2018 \\
\hline DL & Dolnośląskie & 0.312 & 0.409 \\
KP & Kujawsko-Pomorskie & 0.268 & 0.255 \\
LB & Lubelskie & 0.403 & 0.429 \\
LS & Lubuskie & 0.266 & 0.296 \\
LD & Eódzkie & 0.371 & 0.373 \\
MP & Małopolskie & 0.381 & 0.455 \\
MZ & Mazowieckie & 0.591 & 0.583 \\
OP & Opolskie & 0.283 & 0.314 \\
PD & Podkarpackie & 0.293 & 0.343 \\
PL & Podlaskie & 0.433 & 0.496 \\
PM & Pomorskie & 0.338 & 0.435 \\
SL & Śląskie & 0.349 & 0.378 \\
SW & Świętokrzyskie & 0.363 & 0.324 \\
WM & Warmińsko-Mazurskie & 0.311 & 0.279 \\
WK & Wielkopolskie & 0.344 & 0.347 \\
ZP & Zachodniopomorskie & 0.353 & 0.322 \\
Average & & 0.354 & 0.377 \\
Standard deviation & 0.077 & 0.084 \\
Vs & & 0.216 & 0.222 \\
\hline
\end{tabular}

Source: own study.

undertake various economic development activities (Devees et al. 2003). Consequently, the low tax capacity of rural and urban-rural municipalities proves their weak tax base resulting from the economic profile and the tax system adopted in Poland, i.e. a large share of agriculture and a small income from PIT and CIT. This suggests that the level of regional authority and the degree of fiscal decentralization may exert an effect on the spatial distribution of income (Schneider 2003).

Significant differences in LGU tax capacity are also important from the point of view of expenses necessary to ensure a certain standard of public services. Thiessen (2003) points out that regional inequalities in infrastructure, education, healthcare and other public services may prevent the full use of production factors.

It should be stressed that the literature on the subject also includes views questioning the economic sense of transfers to rural or less urbanised regions, where the effects of the metropolitan area are absent (Boldrin, Canova 2001). The majority of representatives of the new economic geography trend claim that there is an intense conflict between economic efficiency and spatially equal distribution of income (Brakman et al. 2004).

The effectiveness of the applied fiscal tools differs from country to country, and therefore there is no universal model of successful fiscal policy in terms of reducing income differences (Paulus et al. 2009). In Poland, LGU tax capacity in terms of voivodeships is, to a small extent, compensated by government institutions' expenditure. Throughout the entire research period, the negative correlation coefficient remained practically within the range $(-0.5 ; 0.2)$. The equalisation mechanisms applied in Poland differ in terms of the supported area or public services. Depending on the purpose of the equalisation mechanism (Martinez-Vazquez, Boex 1997), the subject of compensation in Poland is the income side and/or expenditure needs. The value of some transfers also depends on the number of inhabitants. Expenditure needs are determined on the basis of algorithms, using weights, taking into account factors such as tax revenues, population density, length of roads, number of schools and children in them, number of teachers, unemployment level and social welfare payments. The above method of financial support is present in Poland only in selected areas: healthcare, education and social assistance, and involves transfers of a vertical nature. In these areas, the Gini coefficient in Poland had the lowest values. Lack of optimal criteria for allocating public funds in the other areas examined by us indicates significantly higher Gini coefficient values. This is particularly evident 
in Poland in the case of the Culture area. Significant cultural events that are financially supported, take place in large cities.

Regardless of the support methods used, the allocation of public funds of government institutions in the long term does not improve differentiation between voivodeships. The minimal changes in the value of the Gini coefficient indicate that the level of variation between LGU in terms of provinces is maintained rather than reduced.

The almost identically low value of the coefficient of variation in the level of LGUs' social situation over eight years indicates a minor role of government institutions' public expenditure in reducing inter-voivodeship differences. This confirms Shah's position (Shah 2007) that equalising transfers should refer to natural variation, not to cost differences reflecting deliberate decisions by local authorities, or to differences in the efficiency of using funds.

Ultimately, the conducted data analysis allows for positive verification of the hypothesis that government institutions' public expenditure across voivodeships in Poland shows low effectiveness in reducing inter-voivodeship social inequalities.

Fiscal decentralization in Poland did not take into account the disparities that had already taken place in the 1980s. The measures adopted for the vertical distribution of public funds were in no way adapted to the current economic and development conditions of the regions concerned. And as our research shows, the policy used in Poland to allocate and redistribute public funds, including government institutions, is not likely to be effective in this area. The case of Poland allows for the conclusion that in the case of Eastern European countries fiscal decentralization may not have a positive effect on improving inter-regional disparities as is the case in highly developed countries (cf. Gil Canaleta et al. 2004, Lessmann 2009, 2012, Rodríguez-Pose, Ezcurra 2011). On the contrary, it can increase disparities between regions. To a large extent, this impact will depend on historical factors and the model of decentralization adopted (mainly fiscal but also on competence-related and political ones) at the very beginning of the change process. Failure to take into account the state and development potential of individual regions in the distribution of public funds may result in an increase in inter-regional disparities. Especially, in the absence of a compensatory policy for the government sector.

Our results also have some implications for the European Union's regional policy. As the EU is striving to harmonise more and more decision-making processes in transnational institutions, supporting not countries but rather their poorest regions is the basis for convergence.

\section{Summary}

Inadequate mechanisms of allocating public funds are an important reason for the low efficiency of expenditure of government sector institutions in the analysed areas. The expenditures consider the size of LGU tax revenues to a small extent, without contributing to the improvement of inter-voivodeship differentiation, either in financial or social terms. As a consequence, fiscal decentralisation does not contribute to the improvement of intervoivodeship social inequalities in Poland.

Regardless of the ongoing discussions on the amount of public funds that should be allocated to the local government sector (depending on the division of tasks performed) since 1990, Poland's tax revenue system is relatively stable. Despite meeting the basic conditions, however, the local government finance system is far from ideal. The disadvantages of the system in force in Poland are manifested primarily in the low share of LGU own revenues, neglecting justified differences in the costs of performing public tasks when shaping local government revenues, an unclear system of financing excessively complex commissioned tasks, the complicated structure of the general subsidy, limiting the possibilities of effectively equalising financial disproportions or discrepancies between the public tasks assigned to local governments, and the financial capacity to manage independently and effectively the performance of these tasks. The current public finances system is guilty not only of a lack of appropriate mechanisms stimulating comparable quality in public services. It also features regulations that objectively induce behaviour 
that, although rational from the point of view of local governments' financial interests, leads to the ineffective use of public funds.

The construction of a correction and equalisation mechanism should be based on the principle of partial compensation of the gap between an entity's fiscal potential and the standard costs of performing public tasks assigned to the LGU. Lower level authorities should be able to cover most of the expenses from local government taxes and other forms of their own income (Blöchliger et al. 2016). This would bring the Polish transfer system closer to the concept of reducing the gap between normatively defined expenditure and income potential, as known from the literature.

\section{References}

Agyemang-Duah W, Kafui Gbedoho E, Peprah P, Arthur F, Sobeng AK, Okyere J, Dokbila JM (2018) Reducing poverty through fiscal decentralization in Ghana and beyond: A review. Cogent Economics 63 Finance 6: 1476035. CrossRef

Alexandru DG, Guziejewska B (2020) Administrative capacity as a reduction in fiscal decentralization, the case of Romania and Polish. Comparative Economic Research. Central and Eastern Europe 23(1) 23: 127-143. CrossRef

Bartolini D, Stossberg S, Blochliger H (2016) Fiscal decentralization and regional disparities. OECD economics department working papers

Blöchliger H, Bartolini D, Stossberg S (2016) Does fiscal decentralization foster regional convergence? OECD economic, policy paper, no. 17. CrossRef

Boadway R (2008) Intergovernmental redistributive transfers: efficiency and equity. In: Ahmad E, Brosio G (eds), Handbook of fiscal federalism. Edward Elgar Publishing, Chelternham. CrossRef

Boldrin M, Canova F (2001) Inequality and convergence: Reconsidering European regional policies. Economic Policy 32

Brakman S, Garretsen H, Gorter J, van der Horst A, Schramm M (2004) New economic geography, empirics and regional policy. An exploratory expedition on their common ground. CPB Netherlands Bureau for Economic Policy Analysis. http://www.hec.unil.ch/mbrulhar/Eurecon/Brakman_etal_05.pdf

Buchanan JM (1950) Federalism and fiscal equity. American Economic Review 40: 583599

Christofakis M, Gaki E, Lagos D (2019) The impact of economic crisis on regional disparities and the allocation of economic branches in Greek regions. Bulletin of Geography. Socio-economic Series 44: 7-21. CrossRef

Devees S, Loabo L, Swanson LE (2003) Local economic development in an age of devolution: The question of rural localities. Rural Sociology 68: 182-206. CrossRef

Encyclopaedia Britannica (2020) Encyclopaedia Britannica, "German-Soviet Nonaggression Pact". https://www.britannica.com/event/German-Soviet-Nonaggression-Pact, accessed 07.092020

Gałecka M, Smolny K (2019) Criteria for the optimal financing model of public theatres. Review of Economic Perspectives - Národohospodářský obzor 19: 119-136. CrossRef

Gil Canaleta C, Pascual Arzoz P, Rapun Garate M (2004) Regional economic disparities and decentralisation. Urban Studies 41: 71-94. CrossRef

Grabiński T, Wydymus S, Zeliaś A (1989) Metody taksonomii numerycznej w modelowaniu zjawisk społeczno-gospodarczych. Warsaw: PWN

Kańduła S (2017) Mechanizmy wyrównywania fiskalnego. Studium empiryczne gmin w polsce w latach 2004-2014. poznań: Wydawnictwo uniwersytetu ekonomicznego w poznaniu 
Kessler AS, Lessmann C (2010) Interregional redistribution and regional disparities: How equalization does (not) work. CEPR discussion paper no. DP8133. https://ssrn.com/abstract $=1718928$ (accessed: 25.01.2021)

Kukliński A (2010) Problem Polski Wschodniej. Doświadczenia i perspektywy [w:] Błaszczuk d j, Stefański M. (red.) Strategiczna problematyka polski Wschodniej. Lublin, Wyższa Szkoła Ekonomii i Innowacji w Lublinie

Kyriacou A, Muinelo-Gallo L, Roca-Sagalés O (2015) Fiscal decentralization and regional disparities: The importance of good governance. Papers in Regional Science 94. CrossRef

Lessmann C (2006) Fiscal decentralization and regional disparity: A panel data approach for OECD countries. Ifo working paper, 25. https://www.ifo.de/DocDL/IfoWorkingPaper-25.pdf

Lessmann C (2009) Fiscal decentralization and regional disparity: Evidence from cross-section and panel data. Dresden Discussion Paper Series in Economics, No. 08/09, Technische Universität Dresden, Fakultät Wirtschaftswissenschaften, Dresden, 7. http://hdl.handle.net/10419/36484 (accessed: 10.09.2021)

Lessmann C (2012) Regional inequality and decentralization: An empirical analysis. Environment and Planning A: Economy and Space 44: 1363-1388. CrossRef

Łuniewska M, Tarczyński W (2006) Metody wielowymiarowej analizy porównawczej na rynku kapitałowym. Warszawa: PWN

Martinez-Vazquez J, Boex LFJ (1997) Fiscal capacity - An overview of concepts and measurement issues and their applicability in the Russian Federation. GSU Andrew Young School of Policy Studies Working Paper, no. 97-3

Mazur A, Witkowska D (2006) Zastosowanie wybranych mierników taksonomicznych do oceny nieruchomości. Ekonomika i Organizacja Gospodarki Żywnościowej 60: 251-258

Młodak A (2006) Analiza taksonomiczna w statystyce regionalnej. Difin, Warsaw

Mohiuddin S, Hashia H (2012) Regional socio-economic disparities in the Kashmir valley (India) - A geographical approach. Bulletin of Geography. Socio-economic Series 18: 85-98. CrossRef

Márquez M, Ramajo J, Hewings JDG (2017) Regional public stock reductions in Spain: Estimations from a multiregional spatial vector autorregressive model. Region 4: 129146. CrossRef

Musgrave RA (1959) The theory of public finance: A study in public economy. Mc GrawHill, New York

Oates WE (1972) Fiscal federalism. Harcourt Brace Jovanovich, New York

Oates WE (1999) An essay on fiscal federalism. Journal of Economic Literature 37: 1121-1149. CrossRef

Oates WE (2006) On the theory and practice of fiscal decentralization. IFIR working paper no. 2006-05. CrossRef

OECD (2019) Making decentralisation work: A handbook for policy-makers. OECD Publishing, Paris. CrossRef

Panizza U (1999) On the determinants of fiscal centralization: Theory and evidence. Journal of Public Economics 74: 97-139. CrossRef

Patrzałek L, Poniatowicz M, Guziejewska B, Kańduła S (2019) Nierówności fiskalne w samorządzie terytorialnym. Wrocław: Wydawnictwo uniwersytetu ekonomicznego we wrocławiu

Paulus A, Čok M, Figari F, Hegedüs P, Kump N, Lelkes O, Levy H, Lietz C, Lüpsik S, Mantovani D, Morawski L, Sutherland H, Szivos P, Võrk A (2009) The effects of taxes 
and benefits on income distribution on the enlarged EU. Euromod Working Paper, No. EM8/09. https://www.econstor.eu/bitstream/10419/64873/1/632176261.pdf (accessed: 15.01 .2021$)$

Pigou AC (2010) The economics of welfare (4th ed.). Macmillan, London

Piketty T (2005) Ekonomia nierówności. Wyd. Krytyki Politycznej, Warsaw

Purbadharmaja I, Maryunani, Ananda C, Santoso D (2019) The implications of fiscal decentralization and budget governance on economic capacity and community welfare. Foresight 21: 227-249. CrossRef

Rodríguez-Pose A, Ezcurra R (2009) Does decentralization matter for regional disparities? A cross-country analysis. SERC discussion paper 25 spatial economic research centre

Rodríguez-Pose A, Ezcurra R (2011) Is fiscal decentralization harmful for economic growth? Evidence from the OECD countries. Journal of Economic Geography 11: 619-643

Romer PM (1994) The origins of endogenous growth. Journal of Economic Perspectives 8: 3-22. CrossRef

Rubolino E (2019) The efficiency and distributive effects of local taxes: Evidence from Italian municipalities. Institute for social and economic research, ISER working paper series

Schneider A (2003) Decentralisation: conceptualization and measurement. Studies in Comparative International Development 38: 32-56. CrossRef

Shah A (1994) A fiscal need approach to equalization transfers in a decentralized federation. World Bank Policy Research Working Paper 1289. Washington, DC

Shah A (2007) A practitioner's guide to intergovernmental fiscal transfers. In: Boadway $\mathrm{R}$, Shah A (eds), Intergovernmental fiscal transfers: Principles and practice. The World Bank, Washington, D.C. CrossRef

Sorens J (2011) The institutions of fiscal federalism. Publius: The Journal of Federalism 41: 207-231. CrossRef

Statistics Poland (2010) Local data bank. https://bdl.stat.gov.pl (accessed: 15.11.2010)

Szabela-Pasierbińska E (2018) Ocena programu operacyjnego Rozwój Polski Wschodniej 2007-2013. Społeczeństwo i Ekonomia 2: 39-51. CrossRef

Thiessen U (2003) Fiscal decentralisation and economic growth in high-income OECD countries. Fiscal Studies 24: 237-274. CrossRef

UNDP - United Nations Development Programme (2013) Human development reports for the year 2010. http://hdr.undp.org/en/content/human-development-report-2010

UNDP - United Nations Development Programme (2020) Human development report 2020 http://hdr. http://undp.org/en/2020-report (accessed: 20.12.2020)

Wong JD (2004) The fiscal impact of economic growth and development on local government revenue capacity. Journal of Public Budgeting, Accounting 6 Financial Management 16: 413-423. CrossRef

Yuanshuo X, Warner ME (2016) Does devolution crowd out development? A spatial analysis of US local government fiscal effort. Environment and Planning A 48: 871890. CrossRef 